\title{
Poznawcza operatywność i własności sądów egzystencjalnych
}

\author{
Jerzy Tupikowski \\ (Papieski Wydział Teologiczny we Wrocławiu, Instytut Filozofii Chrześcijańskiej)
}

\section{Uwagi wstępne}

Jednym z najczęściej przywoływanych oraz dyskutowanych terminów na gruncie całego dyskursu filozofii, ale również w obrębie innych dziedzin nauki, jest pojęcie prawdy. Jest ona bowiem prymarną i z wielu powodów konstytutywną wartością poznawczą, która nie tylko stanowi cel naukowych przedsięwzięć, ale również jest taką rzeczywistością, która zaznacza swoją obecność, choćby w sposób całkowicie zalążkowy i tylko presuponowany, już u ich źródeł, ale także na mocy intuicji, poniekąd w całym procesie ich realizacji. Podejmując w tym artykule problematykę operatywności sądów egzystencjalnych ${ }^{1}$ jako głównych nośników realności istnienia świata i wtórnie - samej prawdy, nie wdając się tutaj w szczegółowe spory prowadzone pomiędzy koncepcjami skrajnymi, między innymi ze sceptycyzmem, relatywizmem, czy też agnostycyzmem ${ }^{2}$, trzeba się zgodzić z tezą, że to właśnie prawda - jej nośność - jest tym gruntem, który funduje i poniekąd porządkuje całą strukturę ludzkich aktów poznawczych pojmowanych jako ich rezultat, a także, $\mathrm{z}$ drugiej strony, samego poznania rozumianego

1 Podjęte w tym artykule analizy są rozwinięciem i aktualizacją problematyki zawartej w moim tekście: Epistemiczna nadprawdziwość i bezznakowość sądów egzystencjalnych, „Quaestiones Selectae" 2012, t. XXI, z. 30, s. 7-22.

2 Zob. m.in. R. Ziemińska, Spór relatywizmu z absolutyzmem na temat pojęcia prawdy, „Roczniki Filozoficzne" 2009, t. 57, z. 1, s. 299, 311-312. 
na sposób czynnościowy ${ }^{3}$. Zasygnalizowana debata wokół fenomenu prawdy i jej sądowych komunikatorów, a więc jej genezy, istoty oraz kryteriów dotyczy zasadniczo jej eksplikacji w horyzoncie epistemicznym (definicyjnym). Naturalnie, zwróćmy raz jeszcze uwagę na to, że konstatacje w tym obszarze są wyjściowe i newralgiczne w całym dyskursie teoretycznym, ale komunikują sobą również wieloaspektowe dyskusje i konsekwencje w przestrzeni całej ludzkiej egzystencji.

\section{Podstawowe aporie}

W zasygnalizowanym kontekście problemowym warto zauważyć, że perspektywa prawdy w jej odsłonie logicznej (epistemicznej) odwołuje się do, czy wręcz domaga się, jej ujęcia oraz reflektowania na bardziej jeszcze pierwotnym, źródłowym gruncie, a mianowicie rozumienia prawdy w jej aspekcie ontycznym. Naturalnie, taki sposób jej poznawczej percepcji i wyjaśniania posiada specyficzne umiejscowienie systemowe w tym znaczeniu, że refleksja na kanwie prawdy w jej charakterystyce ściśle ontycznej (z metafizycznego punktu widzenia - wyjściowej) pojawia się głównie w nurcie filozofii klasycznej, a wyrażając się bardziej precyzyjnie - w obszarze analiz w ramach tzw. filozofii realistycznej, filozofii bytu kojarzonej, zwłaszcza na gruncie polskim, z lubelską szkołą filozoficzną ${ }^{4}$.

W tym bowiem ujęciu absolutnie pierwszoplanowym polem odczytywania i reflektowania prawdy jest sam istniejący realnie byt oraz jego ontyczne uposażenie, czyli wewnętrzna struktura, poniekąd nakłaniająca bezpośrednio do formułowania pytań o fundamentalne własności bytu, co w tym wypadku suponuje uwzględnienie całej architektury jego charakterystyk transcendentalnych. Ponadto w tej poznawczej optyce całkowicie wyróżnione znaczenie i rola przypada swego rodzaju transmiterom tychże powszechnych (transcendentalnych) właściwości bytu, jakimi są dwa typy sądów: sądy predykatywne (podmiotowo-orzecznikowe) oraz, w sposób bardziej jeszcze pryncypialny, sądy egzystencjalne jako najbardziej źródłowe i epistemicznie najbardziej doniosłe komunikatory

Por. A.B. Stępień, Wstęp do filozofii, Lublin 1995, s. 68.

4 Porządkowania sposobu rozumienia „filozofii klasycznej” jako sui generis synonimu „lubelskiej szkoły filozoficznej”, bądź też „lubelskiej szkoły filozofii klasycznej”, dokonują - z metodologicznego punktu widzenia - A. Bronk i S. Majdański w artykule: Klasyczność filozofii klasycznej („Roczniki Filozoficzne” 1991-1992, t. 39-40, z. 1, s. 367-391). 
bytu, a zatem zasadniczo wszystkiego, co istnieje i jako takie jest odczytywane $\mathrm{w}$ najgłębszym realizmie, to znaczy w samym akcie jego realnego istnienia ${ }^{5}$.

Dla systematyzacji dalszych analiz podjętych w niniejszym artykule na planie refleksji wokół prawdy, głównie w jej aspekcie ontycznym, zasadne wydaje się przypomnienie kilku węzłowych ustaleń w obrębie tak natury, jak i struktury sądów egzystencjalnych jako jej naturalnych komunikatorów. Odnotujmy ponownie, że odsłaniają się one jako podstawowe nośniki poznawczej komunikowalności ujawniającego się w ludzkich aktach poznania rzeczywistości. W związku z powyższym należy zaznaczyć to, że wszelka afirmacja, przede wszystkim afirmacja samego istnienia bytów, a więc tego wszystkiego, co jest-istnieje, zachodzi na płaszczyźnie artykulacji i obowiązywalności tych właśnie sądów. Ich pierwotna nośność charakteryzuje się tym, że prezentują się one jako spontaniczne oraz bezpośrednie znaki znajdujące się u samych korzeni stwierdzania realności świata w jego rzeczywistym bytowaniu 6 .

Kompozycja sądu egzystencjalnego komunikuje dwie konstytutywne jego składowe, a mianowicie to, że: (i) niesie on w sobie zrelacjonowanie do dowolnego (jakiegokolwiek) przedmiotu, a więc dowolnie danej treści $(X)$, jakiegokolwiek bytu oraz, co jest w tym miejscu czymś newralgicznym, (ii) ujawnia się tutaj kluczowy rys, jakim jest moment afirmatywny, którego poznawcza moc odnosi do najbardziej fundamentalnej afirmacji, jaką jest prosty w zasadzie komunikat - coś (cokolwiek jako przedmiot $X$ ) istnieje $e^{7}$. Wspomniany moment wyraża zatem faktyczne (w znaczeniu: 'realne') istnienie danego, jakiegokolwiek $X$. Można w związku z tym ustaleniem stwierdzić, że w swojej podstawowej funkcjonalności sąd egzystencjalny, jego epistemiczna operatywność, jest w istocie jedyną platformą poznawczą, która - już na etapie poznania potocznego, czysto zdroworozsądkowego i afirmuje (aspekt metafizyczny), i komunikuje (aspekt epistemologiczny) jednocześnie strukturę rzeczywistości jako ontyczny kompleks istniejących realnie faktów.

Zob. szerzej: A. Gondek, Egzystencjalny sąd, w: Powszechna Encyklopedia Filozofii, t. III, red. A. Maryniarczyk i in., PTTA, Lublin 2002, s. 45-51.

6 Por. J. Tupikowski, Realizm i analiza. Zarys metafizycznego rozumienia świata rzeczy i osób, Wydawnictwo Salwator, Kraków 2018, s. 81-82.

7 Zob. na ten temat: E. Gilson, Byt $i$ istota, tłum. D. Eska, J. Nowak, Instytut Wydawniczy PAX, Warszawa 2006, s. 61 i nn. Zob. analizy, które w związku z tym tematem przeprowadza Piotr S. Mazur w pracy: Metafizyka istnienia człowieka, Wydawnictwo Naukowe Akademii Ignatianum w Krakowie, Kraków 2018, s. 15 i nn. 
Zasygnalizowane wyżej wstępne ustalenia prowadzą do prostego w swej warstwie znaczeniowej wniosku, który pomimo swojej prostej czytelności, wydaje się uwagą niosącą istotną informację. Wynika stąd bowiem, że na gruncie przywoływanego tutaj epistemicznego realizmu, czy też sui generis naturalnej zdroworozsądkowości, ujawnia się możliwość wstępnego rozumienia i formułowania takich sądów (zdań-twierdzeń) o otaczającym człowieka świecie, które w perspektywie kolejnych poznawczych czynności są jak najbardziej niezbywalne i pierwszoplanowe. Sądy egzystencjalne, bądź konsekwentnie się wyrażając: sądy pierwsze, odznaczają się bowiem tym ich naturalnie wewnętrznym, poznawczym komunikatem, który wyraża i więcej - reprezentuje byt w samym akcie jego istnienia ${ }^{8}$.

Przedstawiona wstępnie własność sądów egzystencjalnych niesie tę pierwszoplanową, poznawczą informację, że byt, a uściślając: byt-podmiot, jest samym faktycznie (realnie) istniejącym bytem. Dochodzi jednak do tego kolejna kwalifkacja tego sądu, która komunikuje to, że tym samym jest on orzeczeniem. Dlatego też należy w tym miejscu skonstatować, że w takiej mierze, w jakiej sądy wtórne, czyli sądy podmiotowo-orzecznikowe (predykatywne), stanowią zasadniczy grunt, który pozwala poznawczo ujmować treści rzeczy, czyli ich wewnętrzną (ontyczną) kompozycję, tak sądy pierwotne, sądy wyjściowe, którymi są sądy egzystencjalne, i odnoszą się do samego rdzenia bytu, i wyrażają go, a więc jego realizm. Odnotujmy w związku z tym, że w odnośnym horyzoncie problematyki Mieczysław A. Krąpiec podkreśla to, że wszelkie, jak się wyraża, „porządki rzeczywistości”, będące rezultatem poznania o charakterze czysto abstrakcyjnym, w pełni pojęciowym, zawsze zakładają ów w zupełności pierwotny, „porządek” rzeczywistości, jakim jest (realne) istnienie bytu w jego niepowtarzalnej konkretności. Autor ten dodaje, że samo istnienie - zawsze istnienie rzeczywiste ludzki intelekt afirmuje i wyraża „pierwotnie i oryginalnie” właśnie w strukturze i nośności sądu egzystencjalnego. Wyprowadza stąd istotny dla toku tych analiz wniosek, że „jest”, to znaczy ,jest” w jego funkcji podstawowej - egzystencjalnej, stanowi bazę względem afirmacyjnej, czyli prymarnej funkcji owego „jest" (,jest” jako łącznika zdaniowego) ${ }^{10}$.

Por. J. Tupikowski, Epistemiczna nadprawdziwość, dz. cyt., s. 8-9.

9 Odnotujmy w tym miejscu wagę poznawczej operatywności metody separacji. Zwraca na to uwagę Piotr S. Mazur - zob. tenże, Zarys podstaw filozofii człowieka. Antropologiczne zastosowanie metody separacji, Księgarnia Akademicka, Kraków 2016.

10 Por. M.A. Krąpiec, Dzieła, t. VIII: Poznawać czy myśleć. Problemy epistemologii tomistycznej, RW KUL, Lublin 1994, s. 270-271. 
Zasygnalizowana wyżej wyjściowa dystynkcja pomiędzy sądami pozwala na poczynienie wstępnego ustalenia, że sądy o strukturze podmiotowo-orzecznikowej (sądy o konstrukcji: „SeP”) ukierunkowują się do treści bytu. Komunikują one ontyczną formę oraz jej zawartość. Wskazują na zakres treści, informując poznający go podmiot, że dany, konkretny byt (coś) jest po prostu jakiś, czyli odsłania jemu właściwy, określony ściśle układ zawartości. Krótko mówiąc: byt jest zawsze czymś, zawsze jest jakąś określoną treścią. Natomiast będące przedmiotem naszego zainteresowania sądy egzystencjalne (sądy o prostej strukturze: „S”) komunikują formę bytu - kompozycję danego stanu rzeczy absolutnie fundamentalną. Ich informatywność jest niezwykle naturalna, ponieważ odnosi się i jednocześnie ujmuje ontyczną podstawę rzeczy, a jest nią sam akt jej realnego istnienia ${ }^{11}$.

Istotne przy tym jest to, że rzeczony tutaj akt istnienia jako akt (realnego) istnienia, akt stwierdzany w sądzie egzystencjalnym nie komunikuje żadnej cechy, jakiejkolwiek własności bytu-rzeczy. Konkluzja, jaka się tu zarysowuje, jest taka, że ten typ sądu nie jest i żadną miarą nie może być zredukowany do operatywności sądów podmiotowo-orzecznikowych. Jego głównym wyróżnikiem jest to, że poniekąd już w punkcie wyjścia nastraja on akty poznania w ontycznym układzie rzeczywistym, tj. u samych podstaw istnienia. Wynika stąd także, że sam fakt istnienia rzeczy jako fakt całkowicie pierwotny nie komunikuje o niej jakichkolwiek treści, mimo że akt (realnego) istnienia jest z pewnością pierwszą racją bytu, a więc racją jego rzeczywistego (za)istnienia ${ }^{12}$.

W tym miejscu warto dodać, że nośność sądów egzystencjalnych stanowi grunt tak samego istnienia rzeczywistości oraz jej ontycznych składowych, jak i jej poznawczej afirmacji. Ta ostatnia odsłania, przywołany wcześniej, sam fakt bycia bytem, ale ponadto stanowi podstawę dla poznania świata w swej istocie pluralistycznego. Oznacza to, że owa afirmacja jest egzemplifikacją sposobu ujęć właściwych metafizyce realistycznej, czyli ujęć o charakterze transcendentalizującym - powszechnym, nie zaś ujęć o charakterze uniwersalizującym, a zatem „zakresowym”13. Dodajmy tu także, że rozumienie - jako specyficzny dobór i układ poznawczych czynności, właśnie czynności na sądach - dotyczy bytu,

11 Por. J. Tupikowski, Realizm i analiza, dz. cyt., s. 82-83.

12 Por. E. Gilson, Byt i istota, dz. cyt., s. 91.

13 Por. J. Tupikowski, Epistemiczna nadprawdziwość, dz. cyt., s. 10; Zob. M.A. Krąpiec, Dzieła, t. VII: Metafizyka. Zarys teorii bytu, RW KUL, Lublin 1995, s. 39-41; Tenże, Dzieła, t. XIII: Język i świat realny, RW KUL, Lublin 1995, s. 94-95. 
który w swej istocie jest złożony, a więc charakteryzujący się jemu właściwą wewnętrzną konstytucją, czyli elementem treściowym, jak i samym, zawsze proporcjonalnym względem niego aktem istnienia, co tym samym eliminuje wszelkie odmiany ontycznego monizmu. Powadzi to do wniosku, że - z tego punktu widzenia - istnieć realnie, czyli być bytem jako bytem, to istnieć jako coś (cokolwiek) w sobie zdeterminowanego - właśnie jako złożenie, a więc ontyczna kompozycja. Z tego wynika, że to rzeczona pierwotna afirmacja istnienia świata komunikuje jednocześnie jego złożoność, czyli jego pluralistyczną architekturę - różnorodność i ontyczną mnogość rzeczy. Oczywiście, ów pluralizm rzeczywistości zakłada konieczność poznawczej afirmacji tego, co go w ogóle umożliwia, a tym samym dostatecznie uniesprzecznia, czyli akt istnienia ${ }^{14}$.

\section{Istotne cechy sądów egzystencjalnych}

We wstępie do tej części analiz zauważmy, że pierwszą i poniekąd całkowicie naturalną własnością sądów egzystencjalnych jest ich epistemiczna spontaniczność. Afirmując konkretny akt istnienia, to znaczy komunikując daną bytowość, fakt istnienia czegoś, sądy te nie są sądami w jakiś sposób nakierowanymi treścią tego, co jest - istnieje. Nie są to zatem sądy refleksyjne (metodycznie pokierowane), lecz w zupełności spontaniczne. Jako takie stanowią one najbardziej gruntowną, a więc i pierwotną intuicję istnienia. Ta właśnie intuicja, na kanwie jego realności konstytuuje zarówno samo sformułowanie, jak i adekwatne wyartykułowanie pojęcia bytu - czegoś istniejącego, czegoś, co jest niezaprzeczalnym, ontycznym faktem. Nadmieńmy, że jakkolwiek samo istnienie - akt istnienia - nie jest w istocie pojęciowalne, niemniej jednak dane, konkretne sposoby istnienia ${ }^{15}$, które chwytają i charakteryzują konkretne treści, pozwalają się ująć na mocy poglądowości pewnych specyficznych pojęć $c^{16}$.

Uwaga ta prowadzi do wniosku, że dzięki swojej poznawczej przejrzystości każdy sąd egzystencjalny komunikuje ściśle określony akt istnienia, będąc jednocześnie podstawą kompozycji tego wyróżnionego epistemicznego ujęcia,

14 Zob. tenże, Dzieła, t. XXII: O rozumienie świata, Wydawnictwo KUL, Lublin 2002, s. 102.

15 Pisałem na ten temat szerzej w monografii Logos i prawda. Od projektu naturalnej teologii do afirmatywnej chrystologiki, Wydawnictwo Salwator, Kraków 2017, s. 33-34.

16 Por. J. Tupikowski, Spór o podstawy teizmu. Racje realnego świata czy kreacja religijnych sensów?, Wydawnictwo PWT, Wrocław 2009, s. 340. 
które cechuje się tym, że jest ono przedznakowe. Dlatego też, poniekąd ze swojej natury, ujęcie takie komunikuje aktową refleksję w perspektywie bezznakowego właśnie i, co z tego wynika, zupełnie spontanicznego ujmowania - odczytywania aktu istnienia (jako aktu istnienia) wszelkich bytów.

Analizowane tutaj przedznakowe sądy, jakimi są sądy egzystencjalne w sensie formalnym, są uprzednie wobec aktów pojęciowania. Sprawia to, że same pojęcia jako swoiste znaki, reprezentacje rzeczywistości posiadają podłoże egzystencjalne. Sam zaś sąd jest afirmowany spontanicznie i pierwotnie w poznawczym układzie rzeczywistości kierującej się działaniem intelektu. Tak zatem sądy egzystencjalne jako nośniki wyrażające realne istnienie tejże rzeczywistości wskazują i to wskazują wprost na (i) epistemicznie otwarte oraz (ii) bezpośrednie zrelacjonowanie poznania i odpowiadającej mu rzeczywistości ${ }^{17}$.

W związku z tym, jak to podkreśla Krąpiec, specyfika sądów egzystencjalnych nie koncentruje się „na przydzieleniu” do konkretnego podmiotu zwykłego orzecznika „byt”, ale w prymarnym i podstawowym rzędzie jest afirmacją aktu istnienia jako aktu istnienia. To właśnie ono jest kluczem zarówno całego porządku ontycznego, jak i epistemicznego. Można w związku z tym stwierdzić, że - przynajmniej w pewien sposób (analogicznie) - sąd orzecznikowy w postaci: „X jest (dowolnym) bytem”, stanowi poniekąd swoistą „pierwszą zamianę”, a więc sui generis "przełożenie” operatywności sądu egzystencjalnego na strukturę pojęć, a zatem - konsekwentnie - na sieć sądów orzecznikowych, co tym samym nie prowadzi do wniosku, że pojęcie jako pojęcie stanowi jakiś przedmiot owego spontanicznego poznania ${ }^{18}$.

Prowadzi to natomiast do konkluzji, że pojęcie jest w swej istocie znakiem, a zatem swoistym medium, na mocy którego podmiot poznający odczytuje zawartość (treść) jawiącej mu się poznawczo rzeczy. Naturalnie, istnienie samo, to znaczy istnienie jako akt (racja) bytu ujawnia się tutaj jako coś absolutnie beztreściowego. Nie jest zatem i żadną miarą nie może być ono reprezentowane poprzez osłonę i nośność jakiegokolwiek znaku, gdyż ze swojej natury nie jest ono nigdy czymś jako ontyczna cecha bądź jakakolwiek własność (kategoria) bytu, bądź nawet cała paleta ontycznych charakterystyk. Wynika stąd zatem, że byt jako (realny) byt istnieje i jako (realnie) istniejący modeluje poniekąd ciągle swe

17 Por. tenże, Realizm prawdy a poznawcza nośność sądów egzystencjalnych, „Studia Philosophiae Christianae" 2011, t. 47, nr 1, s. 74-75.

18 Por. M.A. Krąpiec, Dzieła, t. I: Teoria analogii bytu, RW KUL, Lublin 1993, s. 105-106; zob. tenże, Dzieła, t. II: Realizm ludzkiego poznania, RW KUL, Lublin 1995, s. 78-81. 
ontyczne uposażenie, czyli w istocie realizuje zróżnicowane układy cech. Tak więc konsekwentnie same pojęcia jako takie reflektowane $\mathrm{w}$ ich naturalnej reprezentatywności okazują się identyczne z naturą bytu uchwyconą aspektywnie, przy czym jednak sama owa natura bytu nie jest tożsama z układem znakowej reprezentacji ${ }^{19}$.

Przywołany tutaj kontekst analiz jest podstawą do wyartykułowania wniosku, że czymś całkowicie fundamentalnym jest tutaj swego rodzaju poznawczy dostęp do oglądu (intuicji) istnienia realnej rzeczy. Nie chodzi zatem w owym punkcie wyjścia o intuicję samego znaku, a zatem jej reprezentacji. Prowadzi to również do konstatacji, że samo tylko aspektywne ujmowanie tożsamości siatki pojęć z treścią istniejących rzeczy, nie komunikuje aktu istnienia, z czego też wynika, że nie może go także adekwatnie przedstawić. Oznacza to w konsekwencji, że reprezentacja - z samej jej natury - w ujętej treści jest zawsze mniej pojemna względem faktycznej treści danego poznawczo stanu rzeczy. Ponadto w związku z tym, że treść każdego konkretnego bytu jest bogato uposażona, intelekt ludzki nie posiada zdolności poznawczej, pełnej jej eksploracji. A zatem poznanie ludzkie jest zawsze poznaniem aspektywnym, z czego też wynika, że umysł człowieka nie dysponuje intuicją wszystkich aspektów poznawanej rzeczy ${ }^{20}$.

Na podstawie powyższych uwag można skonstatować, że poznawcze ujęcie bytu w jego realności, czyli poznanie rejestrujące realną rzecz wprost, czyli bez pośrednictwa jakichkolwiek znaków, jest gruntem dla wszelkiego - wtórnego względem niego - typu poznania. Tym samym stanowi jego konieczną rację epistemiczną. Zarysowuje się więc tutaj i ta uwaga, że każdy dany w poznaniu realny przedmiot poznania umożliwia wszelkie (wtórne) akty, chwytające z różnych innych punktów widzenia (aspektów poznania) poznawcze dane. Ustalenie to odnosi się tak do aktów poznania intelektualnego, jak i wszystkich odsłon poznania opartego na pracy zmysłów, co jeszcze dodatkowo podkreśla ich naturalną odpowiedniość ${ }^{21}$.

Wszystko to sprawia, że to pierwotne medium rzeczywistości, jakim jest operatywność sądu egzystencjalnego nie stanowi jedynie afirmacji samego tylko podmiotu, lecz jest odzwierciedleniem i afirmacją jego realnego istnienia. Istnienie bowiem jako akt bytu - to w metafizyce Krąpca i innych przedstawicieli

\footnotetext{
19 Por. J. Tupikowski, Epistemiczna nadprawdziwość, dz. cyt., s. 11-12.

20 Por. M.A. Krąpiec, Poznawać czy myśleć, dz. cyt., s. 266.

21 Por. J. Tupikowski, Realizm i analiza, dz. cyt., s. 110-111.
} 
tomizmu egzystencjalnego jest kluczowe - nie jest redukowalne do jego treści. Stąd też istnienie jako takie (istnienie jako fundamentalny akt bytu), nie podlega zabiegowi pojęciowania w jego zwykłym znaczeniu. Istnienie jakichkolwiek stanów rzeczy, istnienie realnych bytów nie jest przedmiotem, który jest poznawczo dany. Nie jest ono dane na płaszczyźnie prostych spostrzeżeń; nie jest również dane w obszarze samej li tylko komunikowalności pojęć. Pojęcia bowiem ujmują i wyrażają jedynie aspekt bytu treściowy. Ten zaś ze swej natury nie mieści w swym wnętrzu aktu istnienia, a zatem także go nie komunikuje. Dlatego też trzeba stwierdzić, że jedynie sąd egzystencjalny jako sąd w pełnym tego słowa znaczeniu pierwotny relacjonuje adekwatnie zrelacjonowanie do istnienia jako (aktu) istnienia. To pozwala na wyprowadzenie podstawowego dla tych refleksji wniosku, a mianowicie tego, że (i) sąd egzystencjalny nie komunikując treści bytu, ale sam fakt jego realnego istnienia i (ii) jest w swej istocie sądem - jak się wyraża Krąpiec - nadprawdziwościowym. Bowiem jako taki, w aspekcie najbardziej źródłowym, afirmuje istnienie rzeczy, z czego wynika - przypomnijmy - że wszystkie pozostałe sądy, jak i nabudowane na ich operatywności akty poznania są całkowicie pochodne ${ }^{22}$.

Przytoczona powyżej kwestia bezznakowości oraz nadprawdziwości sądów egzystencjalnych odwołuje także do fundamentalnej na gruncie metafizyki realistycznej problematyki, a mianowicie do zagadnienia wewnętrznej struktury bytu. W tym kontekście sam sąd egzystencjalny, będący komunikatorem jego ontycznego rdzenia, czyli istnienia, oraz nabudowany na nim sąd podmiotowo-orzecznikowy, będący z kolei zasadniczym nośnikiem prawdy, ukazuje się jako poznawczy grunt racjonalności i komunikowalności samej ontycznej substruktury. Ciekawe w tym miejscu jest to, że z drugiej strony, sam sąd egzystencjalny - jego bytowa i poznawcza operatywność - zyskuje nieco głębsze jeszcze uzasadnienie. Otóż jest on bardziej jeszcze zrozumiały w tle tej uzupełniającej uwagi, że ontyczna kompozycja rzeczywistości mieści w sobie ów funktor, który (i) odsłania się jako transcendentny wobec treści oraz (ii) są zdolne wyrazić same akty poznawcze - akty intelektualne.

Wynika stąd, że istnieje jakby drugie dno bytu jako ten jego aspekt, który wymyka się możliwości uchwycenia go w siatce pojęć, jak również na sposób ujęć definicyjnych. Okazuje się więc, że jedynym poznawczym narzędziem zdolnym ten charakter rzeczy adekwatnie uchwycić i zakomunikować jest sąd ściśle egzy-

22 Zob. M.A. Krąpiec, Język i świat realny, dz. cyt., s. 92-93, 95. 
stencjalny. Dopiero bowiem jego operatywność za każdym razem bądź afirmuje podmiot, bądź też dokonuje negacji jego istnienia. Stanowi on zatem podstawę wszelkiej poznawalności i konsekwentnie - zrozumiałości świata. A w związku z tym, że pojęcie bytu, jak to podkreśla Krąpiec, jest „pierwszą konceptualizacją istnienia”, dlatego też i sąd orzecznikowy, przybierający strukturę: „X jest dowolnym bytem", stanowi tym samym pierwszą konwersję, a równocześnie stanowi pierwszy sui generis przekład komunikowalności sądu egzystencjalnego na - ze swej natury prawdziwościową - nośność sądu podmiotowo-orzecznikowego ${ }^{23}$.

Ponadto wskazane wyżej zrelacjonowanie układu sądów egzystencjalnych oraz sądów predykatywnych upewnia o tym, że sam ludzki intelekt, w jego zwrotności względem danego mu poznawczo przedmiotu, jest poniekąd nieustannie ukierunkowywany przez niego samego interioryzowaną strukturą rzeczy. Umożliwia to również poczynienie refleksji na płaszczyźnie dyskusji wokół osi poznawczej: podmiot - przedmiot. Wszystko bowiem, co jawi się w polu poznawczego działania podmiotu, a więc cokolwiek on poznaje, jest wydobywane $\mathrm{z}$ ontycznej architektury samego tylko bytu. $Z$ tego punktu widzenia treść jego poznania, a więc wszystko to, co ustala, nie nosi tutaj cech apriorycznych, a więc w nie jest czymś (przed)założonym. Stawia się tutaj tezę, że interioryzowane ciągle przez intelekt dane poznawcze mają swoje źródło w samych faktach wydobywanych $\mathrm{z}$ układu rzeczywistości, z czego wynika, że nie są one (apriorycznie) konstruowane przez sam poznający podmiot. Prowadzi to zatem do wniosku, że poznający intelekt, opierając się na fakcie operatywności sądów egzystencjalnych, niejako ze swej wewnętrznej natury kieruje się realizmem bytów, jakie jawią się w jego zasięgu ${ }^{24}$.

W tym miejscu warto raz jeszcze dodać, że refleksje wokół bytu dokonują się zasadniczo w horyzoncie aktów poznania spontanicznego, z czego też wynika, że są to $\mathrm{w}$ istocie akty przedrefleksyjne. W tym właśnie kontekście sądy egzystencjalne koncentrują się na afirmacji aktu istnienia, czyli uwypuklają sygnalizowane już wcześniej „jest” w jego aspekcie ściśle egzystencjalnym. To „jest” jest prymarne względem „jest” w charakterze orzecznika. Stąd też funkcja „jest” czysto egzystencjalna, która jest podstawą całego procesu poznawczej prawdziwości transmitowanej w układzie sądów predykatywnych, jest gruntem transcendentalności, tak poznania, jak i języka ${ }^{25}$. Sądy egzystencjalne zatem odsłaniają

23 Tenże, Realizm ludzkiego poznania, dz. cyt., s. 566-567; por. J. Tupikowski, Realizm prawdy, dz. cyt., s. 76-77.

24 Por. M.A. Krąpiec, Dzieła, t. X: Człowiek i prawo naturalne, RW KUL, Lublin 1993, s. 90-92.

25 Analizę bogactwa rozumienia istnienia przedstawia Jacek Wojtysiak w swoim tekście: Czym jest 
się jako nieredukowalne żadną miarą do skali nośności sądów orzecznikowych. Dzieje się tak z uwagi na to, że ich formalna struktura jest bezorzecznikowa ${ }^{26}$. Dlatego też fundamentalna funkcja sądów egzystencjalnych bazuje na odzwierciedlaniu afirmacji istnienia wszystkiego, co istnieje, a więc każdej rzeczy w jej realizmie. Oznacza to, że w ich epistemicznej funkcjonalności realizuje się taka poznawcza łączność, która jest pierwotnie źródłowa i jako taka jest tym samym absolutnie niezapośredniczona, gdyż jest w swej istocie bezznakowa - nie zakłada jakiejkolwiek konceptualizacji ${ }^{27}$.

Dochodzi zatem tutaj do pewnego rodzaju styczności aktów poznawczych z samą rzeczą jako właściwym przedmiotem poznania. Można więc powiedzieć, że (i) sąd egzystencjalny jako taki istnieje poniekąd wprost, w znaczeniu - jest on chwytany bezpośrednio, ponieważ zaznacza swą obecność w samej afirmacji istnienia bytu. Dodajmy jednak i to, że (ii) jest również ujmowany w sposób pośredni, a mianowicie na kanwie uchwycenia treści istniejącej rzeczy. Oznacza to, że w kompozycji tego sądu sam aspekt asertywny ujawnia się jako w pewnym sensie narzucony faktycznością, ostrością istnienia poznawanego stanu rzeczy (przedmiotu poznania). Zachodzi zatem w tym miejscu skorelowanie nośności sądu egzystencjalnego z epistemiczną eksploracją rozumu szczegółowego ${ }^{28}$. Tak zatem intelekt potwierdza istnienie danej konkretnej rzeczy, której pewien (wybrany) szczegółowy aspekt odsłania poznawczo praca zmysłów i właśnie to (konkretne) istnienie synchronizuje z reprezentowaną przez owe zmysły konkretnością, przydając tym samym jakiś nowy sens, nowy aspekt, który ostatecznie przekonuje o tym, że faktyczne (realne) istnienie tejże rzeczy jest jej (własnym) istnieniem. Jak to potwierdza treść transcendentale odrębności, jest istnieniem danej rzeczy jako (tej oto) rzeczy w jej konkretności (transcendentalnie rozumianej ontycznej odrębności $)^{29}$.

W świetle powyższych uwag należy teraz podkreślić to, że sądy egzystencjalne, mimo że ujawniają jakieś podobieństwo względem sądów predykatywnych, co ma miejsce z uwagi na ich dwuwyrazową architekturę, to jednak nie są i nie mogą

istnienie?, w: S. Swieżawski: osoba i dzieło, red. J. Czerkawski, P. Gut, Wydawnictwo KUL, Lublin 2006, s. 141-151.

26 M.A. Krąpiec, Dzieła, t. XI: Byt $i$ istota. Św. Tomasza „De ente et essentia” przekład i komentarz, RW KUL, Lublin 1994, s. 72-74.

27 Por. J. Tupikowski, Epistemiczna nadprawdziwość, dz. cyt., s. 14.

28 Zob. Z.J. Zdybicka, Partycypacja bytu. Próba ustalenia relacji między światem a Bogiem, TN KUL, Lublin 1972, s. 106-107.

29 Por. M.A. Krąpiec, Realizm ludzkiego poznania, dz. cyt., s. 406-407, 450, 453. 
być do nich redukowane. Wszak sąd egzystencjalny jest ze swej natury sądem bezorzecznikowym. Poznawcze komunikaty w postaci: „Coś istnieje”, „Coś jest”, zdradzają walor czysto egzystencjalny, a więc jako wyrażenia (stricte) egzystencjalne nie występują w tych przypadkach w funkcji samego tylko orzecznika ${ }^{30}$. Stanowią natomiast wyrażenie pierwotnej afirmacji istnienia, a zatem potwierdzenia realności owego czegoś - jakiegokolwiek bytu ${ }^{31}$.

Warto również dodać, że sam akt afirmujący realne istnienie bytu dokonuje się poza płaszczyzną jakichś rozgrywających się w tym obszarze refleksji. Takie ujęcie bowiem, które jest ujęciem bezpośrednim, jako właśnie proste oraz bezpośrednie, gwarantuje ujmowanie i czytanie rzeczywistości wprost, to znaczy w ujawnianiu się jej bezwzględnie pierwotnego realizmu. Konkluzja, która się tutaj pojawia jest wyjątkowo intuicyjna, a jej treść pozwala na (intuicyjnie proste) stwierdzenie, że rzeczywistość, jaka ona faktycznie jest, odsłania się poznawczo w jej oryginalności. Stąd właśnie wyrażanie konkretnego (i realnego) istnienia, jakie zachodzi w układzie sądów egzystencjalnych, stanowi ten źródłowy i pierwotny akt, który lokuje poznającego człowieka naprzeciw samej rzeczywistości i jej ontycznego bogactwa ${ }^{32}$.

Wskazane wydaje się jeszcze raz zaznaczyć kwestię podstawową, jaką jest aspekt bezznakowości, a zatem i całkowitej bezpośredniości poznawczych ujęć sądów egzystencjalnych. $\mathrm{Z}$ tą kwestią w ścisłym związku pozostaje i ta, że sądy te jako sądy naturalnie pierwotne, tzn. ujmujące rzeczywistość najbardziej źródłowo, są ponadprawdziwe. Są bowiem koniecznym podłożem dla samej prawdziwości, jak i jej komunikowalności w odsłonie wszelkich sądów wtórnych, głównie sądów podmiotowo-orzecznikowych. Wynika z tego, że to sama prawda jako prawda jest naczelnym protokołem tego typu (i) adekwatnego i jednocześnie (ii) pełnego poznania, którym są akty sądzenia. Co ciekawe, sam sąd predykatywny, który ujawnia się tutaj jako naturalny przekaźnik prawdy, w swej poznawczej siatce komunikuje intelektualny - przezroczysty - znak faktycznego istnienia. Jest on ściśle określoną strukturą treści, która się odsłania jako realnie skonkretyzowana i ujęta w samej rzeczy. Ta właśnie struktura uwidacznia się w aktach sądzenia ${ }^{33}$.

\footnotetext{
30 Na ten temat zob. obszerne wyjaśnienia J. Wojtysiaka w jego pracy: O słowie „być”. Z teorii wyrażeń egzystencjalnych $i$ ich filozoficznego zastosowania, TN KUL, Lublin 2005.

31 Por. J. Tupikowski, Epistemiczna nadprawdziwość, dz. cyt., s. 15.

32 Por. tenże, Realizm prawdy, dz. cyt., s. 79-80.

33 Por. tenże, Realizm i analiza, dz. cyt., s. 112, 118-119.
} 
Konsekwentnie zatem sądy wyjściowe, którymi są sądy egzystencjalne, są istotnie sądami (nad)prawdziwościowymi, ponieważ odsłaniają swoje wewnętrzne zrelacjonowanie do tego aspektu bytu, który chwyta i ujawnia konkretny układ treści w bycie jako fakcie istniejącym. Tak więc, w gruncie rzeczy, to w sądach egzystencjalnych wprost oraz pośrednio w całej kompozycji transcendentalnych cech bytu intelekt poniekąd wiąże się poznawczo z obrazem, znakiem konkretnie danego istnienia. Dodatkowo umacnia to ich epistemiczną adekwatność, czyli także ich sprawdzalność, przez co poznawana rzeczywistość jest (bardziej jeszcze) weryfikowalna. Naturalnie, prowadzi to do konkluzji, że każdy rodzaj poznania komunikowanego za pomocą układu znaków, czyli de facto poznania, które chwyta naturę danych w poznaniu rzeczy, nie jest poznawczym aktem fundamentalnym, w znaczeniu - źródłowym, lecz zakłada czytanie świata bezpośrednie, a więc na ile to tylko możliwe, w jego realnym istnieniu. Jedynie takie poznanie wyklucza pośredniczenie jakiegokolwiek znaku. Natomiast w takim wypadku jest ono aktem prostym, ponieważ nie zakłada takich składowych, które - dla swej weryfikacji - domagałyby się potwierdzenia w sieci jakiś znaków. Ostateczny więc wniosek, jaki na tym etapie analiz się narzuca, jest taki, że (pierwotna) afirmacja istnienia rzeczywistości jest pierwszą i podstawową racją bytu wobec samego aktu poznania jako takiego ${ }^{34}$.

\section{Funkcjonalność sądów egzystencjalnych}

W tej części analiz należy zwrócić uwagę na to, że istnieją dwa typy źródłowych sądów formułowanych o świecie. Są nimi sądy egzystencjalne bezpośrednie, a zatem te, które komunikują istnienie rzeczy wprost, wyrażają sam realizm istnienia w jego sui generis naoczności, a także sądy egzystencjalne pośrednie, które ujawniają się w polu, owszem, afirmacji istnienia czegoś, ale samo stwierdzanie realności tego istnienia jest rezultatem pewnego typu refleksji i rozumowań, co też zakłada i domaga się akceptacji jakichś dodatkowych faktów bądź jakiejś uzupełniającej, wyjaśniającej teorii, która to istnienie adekwatnie uzasadnia. Dobrym przykładem takiego rodzaju sądu jest zdanie-sąd - „Bóg istnieje” ${ }^{35}$.

34 Por. tenże, Poznawać czy myśleć, dz. cyt., s. 259 i n., 262.

35 Zob. A.B. Stępień, Studia i szkice filozoficzne, t. I, red. M.A. Krąpiec, T. Szubka, TN KUL, Lublin 1993, s. 194-195; zob. M.A. Krąpiec, Dzieła, t. V: Struktura bytu. Charakterystyczne elementy systemu Arystotelesa i Tomasza z Akwinu, RW KUL, Lublin 1995, s. 287. 
W tym szczególnym wypadku trzeba jednak od razu podkreślić, że sąd egzystencjalny pośredni, którego treścią jest afirmacja istnienia Boga, w swej operatywności stanowi kres wszelkich, racjonalnych uniesprzecznień metafizyki ${ }^{36}$. $\mathrm{W}$ tej konkretnej sytuacji wszelkie inne sądy, a więc, przykładowo, sądy mające za cel uchwycenie Jego natury, nie przydają w zasadzie żadnych dodatkowych informacji. Mogą więc one być jedynie sądami (zdaniami), które pojawiają się tutaj jako sądy niesprzeczne z owym węzłowym, który stwierdza samą konieczność istnienia Boga ${ }^{37}$. Wypływa stąd ważny wniosek, a mianowicie ten, że konieczność afirmacji Jego istnienia lokuje się w sądzie egzystencjalnym pośrednim, a zatem takim sądzie, który się odsłania jako (specyficznie) metafizykalne przekładanie sądów bezpośrednich na sieć pojęć i samego rozumienia bytu ${ }^{38}$.

Warto także rozważyć inne ontyczne sytuacje, jak w przypadku analizy istnienia bytów materialnych, gdzie ich istnienie jest ujmowane poznawczo jako materialne lub niematerialne, a więc w zależności od samego aspektu ujęcia. Oznacza to, że jeśli podkreśla się fakt realizmu różnicy pomiędzy istnieniem (aktem istnienia), a istotą rzeczy (jej naturą, właściwościami), wtedy można zauwa$\dot{z} y c ́$, że ujawnia się ono jako coś absolutnie różnego od materii. W tym wypadku jest ona swego rodzaju znakiem istoty. Samo istnienie natomiast stanowi tu ostateczny akt treści (istoty) i dlatego też, właśnie jako akt, nie jest ono czymś materialnym. Trzeba zatem skonstatować kolejny raz, że istnienie jest poznawalne wprost. Ponadto jeśli materia jako materia stawia pewien naturalny poznawczy opór, to tym samym musi być ona przez poznający ją intelekt (intencjonalnie) zdematerializowana ${ }^{39}$.

Zauważmy przy tym, że analogiczna prawidłowość z jej konsekwencjami nie dotyczy jednak (aktu) istnienia, ponieważ to - niejako ze swej natury - nie jest, nie musi być poddawane zabiegowi owej poznawczej dematerializacji. Jest ono wszak - przypomnijmy - stwierdzane, afirmowane źródłowo w funkcjonalności sądów egzystencjalnych. Natomiast z innej jeszcze poznawczej perspektywy rzeczone tutaj istnienie rzeczy materialnych ujawnia się poniekąd jako materialne. Ta z kolei prawidłowość zachodzi z uwagi na to, że istnienie, będąc aktem - jako

\footnotetext{
36 Por. J. Tupikowski, Realizm i analiza, dz. cyt., s. 164.

37 Na ten temat zob. analizy, jakie przeprowadza Wojtysiak w tekście: O tym, jak dowieść istnienia Boga, w: Filozofia religii. Kontrowersje, red. J. Hołówka, B. Dziobkowski, Warszawa: Wydawnictwo Naukowe PWN 2018, s. 75-100.

38 Por. M.A. Krąpiec, Struktura bytu, dz. cyt., s. 290-291.

39 Por. J. Tupikowski, Realizm prawdy, dz. cyt., s. 82-83.
} 
aktem materii, czyli czegoś $\mathrm{w}$ swej istocie czysto potencjalnego, w zrelacjonowaniu do samej materii - odsłania się jako coś transcendentalnego. Staje się to jeszcze bardziej czytelne, gdy bierze się pod uwagę i to, że jeśli istnienie jest (faktycznie) istnieniem rzeczy materialnej, to tym samym poza kontekstem materii właśnie nie może być ono ani adekwatnie ujęte, ani też zreflektowane. Ostatnio poczyniona uwaga przekonuje, że intelekt właściwie nie może ująć istnienia jako istnienia (jako aktu bytu) w całkowitej izolacji od elementu potencjalnego, jakim jest metafizycznie rozumiana materia. Dochodzi zatem tutaj do zrelacjonowania samego istnienia i odsłony bytu-rzeczy w jej materialnym aspekcie ${ }^{40}$.

$\mathrm{Z}$ uwag tych wypływa wniosek, że sąd egzystencjalny jest takim specyficznym aktem umysłu, który na płaszczyźnie swego poznawczego oddziaływania jest swego rodzaju łącznikiem względem afirmacji innego aktu, to znaczy - w tym wypadku - aktu istnienia (materialnego) przedmiotu. Sama jego architektura sprawia, że istnienie jako niezbywalny grunt realizmu rzeczywistości objawia się w obszarze ludzkiej myśli, co też oznacza, że jest takim w pełni wyróżnionym sądem, który afirmuje i komunikuje istnienie rzeczy i to komunikuje z jej naczelnym aktem, jakim pozostaje akt istnienia. Ponadto sąd egzystencjalny wiąże w poznaniu (i wtórnie - w myśleniu) to, co w sieci realnych stanów rzeczy i tak jest już naturalnie zrelacjonowane. Zarysowujące się tutaj egzystencjalne pojęcie oraz (wtórnie) rozumienie bytu stanowi podstawowy i operatywny instrument względem procesu myślenia, który (przekonują o tym inne akty poznania) uwidacznia się w palecie sądów predykatywnych ${ }^{41}$.

Inną jeszcze funkcją sądów egzystencjalnych jest fakt, że odnoszą się one do różnych typów relacji, jakie mają miejsce w poznawczym obszarze: podmiot - przedmiot. Mianowicie, istnieje taki typ sądów egzystencjalnych, które swoją nośnością afirmują istnienie bytów (przedmiotów) zewnętrznych, to znaczy stwierdzają rzeczywiste istnienie rzeczy poza samym poznającym podmiotem. Są jednak i takie sądy, których operatywność wyraża afirmację istnienia podmiotowego, to znaczy w takim wypadku - „ja” poznającego podmiotu. Biorąc pod uwagę pierwszą ich grupę, sprawa wydaje się mniej złożona, ponieważ prosta afirmacja istnienia rzeczy (zewnętrznych) jest wprost przyporządkowana wobec poznawczego ujmowania ich treści. W drugiej zaś sytuacji, samo stwierdzenie, jak i wyrażenie istnienia dane jest poniekąd od wewnętrznej strony bytu. W tym

40 Por. tenże, Epistemiczna nadprawdziwość, dz. cyt., s. 17.

41 Por. M.A. Krąpiec, Realizm ludzkiego poznania, dz. cyt., s. 453-454. 
wypadku podmiot niejako intuicyjnie i w całkiem naturalny sposób przeczuwa, że ujawniające się „ja” jest czymś istotowo różnym od wszystkiego tego, co może być ujęte jako w różnych aspektach „moje”"42.

$\mathrm{Z}$ uwag tych wynika, że afirmacja własnej jaźni podmiotu - podmiotu (siebie), który po prostu istnieje i tym samym uzasadnia wszelkie akty ujmowane i reflektowane jako wieloaspektowo "moje” względem „mnie”-,ja” podmiotu, jest specyficznym wyakcentowaniem istnienia owego podmiotowego ,ja”. W tej perspektywie zyskuje ono jednocześnie rysy immanentne i transcendentne w stosunku do wszystkich tych aktów odczytywanych w różnych poznawczych płaszczyznach jako „moje”. Oznacza to, że sam sąd egzystencjalny dotyczy szczególnie doniosłej kwestii, jaką jest i doświadczenie, i wyartykułowanie własnej egzystencji podmiotu. Tym samym podkreśla to kolejny raz bezwzględny prymat i transcendencję istnienia względem treści, która w zasygnalizowanym tutaj polu personalnym prezentuje swoje wielopostaciowe oblicze. Chodzi tu bowiem o „moje” w sensie posiadania, o „moje” w sensie psychicznym, a także „moje” na płaszczyźnie duchowej ${ }^{43}$.

Ponadto zarysowana tutaj problematyka transcendencji osoby wobec natury - natury jako „zdeterminowanego źródła działania”, komunikuje to, że podmiot, jakim w tym wypadku jest byt osobowy, jest istotą zupełnie wyróżnioną. Zatem człowiek ujawnia się tutaj jako podmiot, który samobytuje, co znaczy, że w sensie ścisłym istnieje w sobie, co także oznacza, że jest bytem-podmiotem (względnie) doskonałym, gdyż istnieje i działa $w$ sobie i dla siebie ${ }^{44}$.

\section{Prawda w horyzoncie sądów egzystencjalnych}

Wniosek, jaki się nasuwa w związku z przeprowadzonymi dotąd analizami, jest taki, że sądy egzystencjalne są podstawowymi nośnikami, które zapewniają kontakt z wszystkimi - oczywiście, wyłącznie aspektywnie - ontycznymi faktami, czyli z otaczającą poznający podmiot rzeczywistością. Nadmieńmy raz jeszcze, że jej ontycznym gruntem jest akt istnienia, który uniesprzecznia i komunikuje sam realizm świata, a także, konsekwentnie - realizm poznania. To ostatnie bo-

42 Zob. tenże, Dzieła, t. IX: Ja - człowiek, RW KUL, Lublin 1991, s. 120 i nn.

43 Zob. tamże.

44 Por. tamże, s. 416 oraz 421 i nn. 
wiem jest odzwierciedleniem sui generis przylgnięcia do bytów - stanów rzeczy, a więc poniekąd jest przyjęciem ich jako intencjonalnej i oczywiście zdematerializowanej własności. Oczywiście, istnienie samo jako konieczny akt bytu - pomimo jego naturalnej (sądowej) poznawalności, jak i odsłaniania się poza siatką pojęć - swoją nośnością nie komunikuje treści, co jednakże nie oznacza, że się nie odsłania w polu świadomości podmiotu. Jako takie, jest ono bowiem odpoznawane oraz afirmowane w układzie sądów egzystencjalnych ${ }^{45}$.

W związku z tym należy stwierdzić, że (podmiotowe - świadome) akty poznania są całkowicie zawieszone na ontycznej zawartości świata, dlatego też żadną miarą nie są one uzależnione od jakiejkolwiek formy aprioryzmu. Okazuje się zatem, że to sama rzeczywistość jest fundamentalnym kryterium prawdziwości, a więc i realizmu tych aktów. Wiążąc te ustalenia $\mathrm{z}$ obowiązywalnością korespondencyjnego rozumienia prawdy, należy podkreślić fakt, że to właśnie na tym gruncie możliwe jest (i) afirmowanie wszystkiego tego, co jest, gdy rzeczywiście zachodzi (rzeczywiście jest-istnieje), i analogicznie - (ii) brak takiej afirmacji w sytuacji, gdy określony stan rzeczy nie zachodzi (faktycznie nie istnieje) ${ }^{46}$.

Kontynuując ten wątek, warto zauważyć, że rzecz-byt analizowany w aspekcie wyjściowym, jakim jest aspekt egzystencjalny, jest (i) fundamentem dla skonstruowania oraz obowiązywalności zasady niesprzeczności oraz (ii) sama zasada niesprzeczności jest swego rodzaju demonstracją treści rzeczy, co głównie dokonuje się w obszarze jej właściwości transcendentalnych. Stąd też sama prawda, prawda w jej ujęciu definicyjnym (epistemicznym), jest refleksem odpowiedniości, jaka ma miejsce pomiędzy tym, co istnieje (samym bytem), a poznającym intelektem. Intelekt, powtórzmy tutaj, na mocy poznawczego ujęcia rzeczy komunikuje intencjonalną z nią adekwatność, bądź też - na gruncie właściwych danych - brak takiej zgodności. Dlatego też prawda - prawda w jej sensie ontycznym jako właściwy i pierwszy przedmiot poznania komunikuje nie tylko zachodzące $\mathrm{w}$ tym kontekście bądź niezachodzące uzgodnienie myśli z istotą (treścią) rzeczy, lecz także jeszcze bardziej i wprost $\mathrm{z}$ jej (realnym) istnieniem ${ }^{47}$.

Tak zatem bogactwo i operatywność zasygnalizowanego klasycznego rozumienia prawdy jako poznawczej wartości nadrzędnej stanowi uwypuklenie przesłanek poznania jako poznania. Inaczej mówiąc, chodzi tutaj o wyakcento-

\footnotetext{
45 Por. tenże, Realizm ludzkiego poznania, dz. cyt., s. 90-91.

46 Por. tenże, Metafizyka, dz. cyt., s. 193.

47 Por. J. Tupikowski, Realizm i analiza, dz. cyt., s. 142-243.
} 
wanie epistemicznej jedności, jaka się realizuje między poznającym intelektem podmiotu a ujawniającym się poznawczo bytem. Oczywiście, w tym obszarze refleksji zasadnicze jest to, aby uwydatnić znaczenie faktyczności, realizmu samego przedmiotu, gdyż to właśnie on uobecnia się w jego ontycznej pierwotności. Wynika z tego, że racją zaistnienia refleksji, także refleksji towarzyszącej, a więc odnoszącej się do funkcjonowania podmiotu, jest absolutnie pierwotna, źródłowa afirmacja istnienia. To prowadzi do wniosku, że sam podmiot jako podmiot, zanurzony poznawczo w danych mu stanach rzeczy i je poznający, odsłania się jako czysty. W związku z tym każda refleksja oraz każde rozumowanie odnoszące się tak do przedmiotu, jak i w jego zrelacjonowaniu do podmiotu, jawi się jako operacja wtórna, ponieważ umieszczona w polu obowiązywalności faktów czysto egzystencjalnych ${ }^{48}$.

Tak więc rzeczywiste istnienie przedmiotu komunikuje się w poznaniu, które jest swego rodzaju znakiem działającego (realnie) podmiotu. Zachodząca w sądzie zgodność tych dwu istot, a więc przedmiotu i poznającego go intelektu, nie jest wyrazem jakiegoś rodzaju zwielokrotnienia w reprezentacji świata, ale jest niezbywalnym osadzeniem i zarazem uzasadnieniem realizmu poznania jako takiego. Prowadzi to do wniosku, że do aktów poznania zachodzącego w sieci sądów, a zatem do jego wewnętrznej specyfiki, nie przynależy jakiś mechanizm suponowania nowej struktury treści, lecz sam fakt konstatacji, czyli przywołanego już wcześniej poznawczego styku danej, nowej konstrukcji treści z istniejącym bytem, czy też z naturalnymi następstwami jej realnego istnienia. A zatem każdy akt poznawczy, jaki się zaznacza w strukturze sądów, jest płaszczyzną odsłaniającą skalę i wagę tej styczności aktów intelektu, który ujmuje zarówno istotę rzeczy, czyli jej treściową architekturę, jak i samo jej istnienie ${ }^{49}$.

Naturalnie, trzeba pamiętać o tym, że poza aktem istnienia jako aktem bytu ujmowanym w operatywności sądu egzystencjalnego nie ujawnia się ani sam rdzeń, a więc faktyczność, realizm rzeczy, ani też nie jest możliwe jakiekolwiek (adekwatne) poznanie, które przecież ze swej natury - przypomnijmy - ma charakter prawdziwościowy. Prowadzi to do prostej konkluzji, że wszelkie układy samej tylko treści, nawet najbardziej obfitej, in abstracto od (aktu) istnienia, nie istnieją. Występującemu tutaj zatem, w pełni naturalnemu, przyporządkowaniu zarówno aspektu treściowego, jak i egzystencjalnego bytu-rzeczy można przypi-

48 Por. M.A. Krąpiec, Byt i istota, dz. cyt., s. 101-102, 107.

49

Por. tenże, Realizm ludzkiego poznania, dz. cyt., s. 89-89, 408-409. 
sać miano proporcjonalnego zintegrowania. Następstwem zachodzącej tu proporcjonalności owych bytowych porządków jest poszerzenie rozumienia zasygnalizowanej wcześniej (względnej) jedności bytu oraz reflektowania go nie tylko na płaszczyźnie obowiązywalności zasady relatywnej tożsamości, lecz także, per analogiam, relatywnej jedności bytu ${ }^{50}$.

Zarysowuje się tutaj wniosek, że w istocie wszystko, co (aktualnie) istnieje, bądź też (potencjalnie) może (za)istnieć, zawiera w sobie realizację: (i) aktualną - w sytuacji realizowanego już faktu, bądź też (ii) potencjalną - w sytuacji dowolnej możliwości jakiejś treści. Oczywiście, jedynie z tym zastrzeżeniem, by rzeczony w tym kontekście aspekt potencjalności nie pozwalał na realizowanie się jakiejkolwiek sprzeczności, gdyż każdą treść można poznać jedynie na gruncie jej realności oraz poza wszelkim polem sprzecznościowym. Warto dodać, że afirmowane w poznaniu sądowym istnienie jako akt bytu jest tutaj poniekąd domniemane, ponieważ poza jego nośnością nie jest możliwe aktualizowanie się - urzeczywistnianie się - jakiejkolwiek realnej bytowości. Stąd też autor monografii Język i świat realny z naciskiem stwierdza, że pierwotna afirmacja istnienia - ta dokonuje się w sądach egzystencjalnych - z samej swej natury jest, jako bezznakowa, nadprawdziwa i jako taka właśnie jest epistemiczną racją w stosunku do każdego innego aspektu prawdy jako najwyższej poznawczej wartości ${ }^{51}$.

\section{Uwagi końcowe}

Podsumowując powyższe analizy skoncentrowane na naturze i operatywności sądów egzystencjalnych, zauważmy, że poza realnością aktu istnienia ujmowanym i komunikowanym przez te właśnie sądy w ich spontaniczności, bezznakowości i nadprawdziwości, nie byłaby możliwa ani faktyczność-realizm bytu $\mathrm{z}$ właściwą mu treścią (jego istotą), ani też istotne - prawdziwościowe poznanie. Tak zatem struktura treści in abstracto od aktu istnienia nie istnieje, gdyż musiałaby być realizowaniem się ewidentnej sprzeczności, ponieważ w takiej sytuacji - na płaszczyźnie ontycznej - byłaby istnieniem czysto potencjalnym, co na płaszczyźnie epistemicznej konsekwentnie oznaczałoby poznanie rzeczy nieistniejących (nierzeczywistych).

50 Por. Z.J. Zdybicka, Partycypacja bytu, dz. cyt., s. 129-130.

51 Por. M.A. Krąpiec, Język i świat realny, dz. cyt., s. 95. 
Stąd też wszystko, cokolwiek istnieje i ewentualnie może istnieć, odznacza się spełnianiem rzeczywistej bądź potencjalnej treści, pod tym jednak koniecznym warunkiem, aby ta ostatnia była jawnym usunięciem realizowania się jakiejkolwiek sprzeczności. Jest to ważne tym bardziej, że wyraźną specyfiką poznania na gruncie metafizyki jest poznanie istotowe (prawdziwościowe), a to dokonuje się jedynie w sytuacji rzeczy istniejącej, a więc wykluczając realizowanie wszelkiej sprzeczności. Afirmowane zatem w sądzie egzystencjalnym istnienie jest w polu tej refleksji (przynamniej) domniemane, bowiem poza jego polem w ogóle nie realizuje się byt jako właściwy przedmiot poznania.

\section{Bibliografia}

Bronk A., Majdański S., Klasyczność filozofii klasycznej, „Roczniki Filozoficzne” 1991-1992, t. 39-40, z. 1, s. 367-391.

Gilson E. , Byt $i$ istota, tłum. D. Eska, J. Nowak, Instytut Wydawniczy PAX, Warszawa 2006.

Gondek A., Egzystencjalny sad, w: Powszechna Encyklopedia Filozofii, t. III, red. A. Maryniarczyk i in., PTTA, Lublin 2002.

Krąpiec M.A., Dzieła, t. XI: Byt i istota. Św. Tomasza „De ente et essentia” przekład $i$ komentarz, RW KUL, Lublin 1994.

Krąpiec M.A., Dzieła, t. X: Człowiek i prawo naturalne, RW KUL, Lublin 1993.

Krąpiec M.A., Dzieła, t. IX: Ja - człowiek, RW KUL, Lublin 1991.

Krąpiec M.A., Dzieła, t. XIII: Język i świat realny, RW KUL, Lublin 1995.

Krąpiec M.A., Dzieła, t. VII: Metafizyka. Zarys teorii bytu, RW KUL, Lublin 1995. Krąpiec M.A., Dzieła, t. XXII: O rozumienie świata, Wydawnictwo KUL, Lublin 2002.

Krąpiec M.A., Dzieła, t. VIII: Poznawać czy myśleć. Problemy epistemologii tomistycznej, RW KUL, Lublin 1994.

Krąpiec M.A., Dzieła, t. II: Realizm ludzkiego poznania, RW KUL, Lublin 1995. Krąpiec M.A., Dzieła, t. V: Struktura bytu. Charakterystyczne elementy systemu Arystotelesa i Tomasz z Akwinu, RW KUL, Lublin 1995.

Krąpiec M.A, Dzieła, t. I: Teoria analogii bytu, RW KUL, Lublin 1993. 
Mazur P.S., Zarys podstaw filozofii człowieka. Antropologiczne zastosowanie metody separacji, Księgarnia Akademicka, Kraków 2016.

Mazur P.S., Metafizyka istnienia człowieka, Wydawnictwo Naukowe Akademii Ignatianum w Krakowie, Kraków 2018.

Stępień A.B., Studia i szkice filozoficzne, t. I, red. M.A. Krąpiec, T. Szubka, TN KUL, Lublin 1993.

Stępień A.B., Wstęp do filozofii, TN KUL, Lublin 1995.

Tupikowski J., Epistemiczna nadprawdziwość i bezznakowość sąów egzystencjalnych, „Quaestiones Selectae” 2012, t. XXI, z. 30, s. 7-22.

Tupikowski J., Logos i prawda. Od projektu naturalnej teologii do afirmatywnej chrystologiki, Wydawnictwo Salwator, Kraków 2017.

Tupikowski J., Realizm i analiza. Zarys metafizycznego rozumienia świata rzeczy i osób, Wydawnictwo Salwator, Kraków 2018.

Tupikowski J., Realizm prawdy a poznawcza nośność sądów egzystencjalnych, „Studia Philosophiae Christianae” 2011, t. 47, nr 1, s. 69-88.

Tupikowski J., Spór o podstawy teizmu. Racje realnego świata, czy kreacja religijnych sensów?, Wydawnictwo PWT, Wrocław 2009.

Wojtysiak J., Czym jest istnienie?, w: S. Swieżawski: osoba i dzieło, red. J. Czerkawski, P. Gut, Wydawnictwo KUL, Lublin 2006, s. 141-151.

Wojtysiak J., O słowie „być”. Z teorii wyrażeń egzystencjalnych i ich filozoficznego zastosowania, TN KUL, Lublin 2005.

Wojtysiak J., O tym, jak dowieść istnienia Boga, w: Filozofia religii. Kontrowersje, red. J. Hołówka, B. Dziobkowski, Wydawnictwo Naukowe PWN, Warszawa 2018, s. 75-100.

Zdybicka Z.J., Partycypacja bytu. Próba ustalenia relacji między światem a Bogiem, TN KUL, Lublin 1972.

Ziemińska R., Spór relatywizmu z absolutyzmem na temat pojęcia prawdy, „Roczniki Filozoficzne" 2009, t. 57, z. 1, s. 299-314.

\section{Streszczenie}

Rdzeniem realizmu metafizyki jest podstawowa kategoria poznawcza, jaką jest poznanie sądowe wyrażające się głównie w operatywności sądów egzystencjalnych i w strukturze sądów predykatywnych. Nosicielami prawdy są prze- 
de wszystkim sądy podmiotowo-orzecznikowe, ale ich epistemiczny status jest uwarunkowany nośnością sądu pierwszego, jakim jest zawsze sąd egzystencjalny. Ten bowiem sąd afirmuje istnienie świata całkowicie spontanicznie i bezpośrednio. Pierwotna zatem afirmacja istnienia dokonuje się w poznawczej nośności sądu egzystencjalnego i z tego powodu ze swej natury jest on sądem nadprawdziwościowym oraz bezznakowym. Jest on bowiem racją prawdy i jako taki staje się gruntem operatywności samych sądów prawdziwościowych, jakimi są sądy predykatywne. Dlatego też, sąd egzystencjalny jest głównym komunikatorem rzeczywistego istnienia świata i jako specyficzny znak prawdy w jej aspekcie epistemicznym (definicyjnym) jest podstawą rozumienia oraz wyjaśniania jego ontycznej architektury.

Słowa kluczowe: istnienie, sąd egzystencjalny, sąd predykatywny, prawda, bezznakowość, byt, rzeczywistość

\section{Summary}

\section{Cognitive operability and properties of existential judgements}

Judicial cognition - the basic cognitive category - expressed mainly in the operability of existential judgements and in the structure of predicative judgements is the core of metaphysical realism. As transmitters of truth primarily serve the subjective and predicative judgements, but their epistemic status depends on the cogency of the first judgement, which is always the existential judgement. It is this very judgement that affirms the existence of the world completely spontaneously and directly. Thus, the initial affirmation of existence takes place in the cognitive cogency of the existential judgement and for this reason, by its very nature, it is a super-intelligible and signless judgement. For it is the raison d'être of truth and, as such, it becomes the basis for the operability of the truth-transmitting/intelligible judgements, which are predicative judgements. Therefore, the existential judgement is the main communicator of the real existence of the world and as a specific sign of truth in its epistemic (defining) aspect, is the basis for comprehending and explaining its ontic structure.

Key words: existence, existential judgement, predicative judgement, truth, signlessness, entity, reality 